\title{
Towards the Establishment of Constitutionalism in Russia
}

\section{INTRODUCTION}

The liberal and democratic trends that began circulating during the Enlightenment as a result of such thinkers as John Locke, JeanJacques Rousseau, and Montesquieu ${ }^{1}$ have become widely accepted as the dominant constitutional paradigm. Not only has democracy established itself firmly on an institutional basis, but democracy has also become a benchmark by which to measure a nation's commitment to the rights and freedoms of its citizens. In the wake of the Cold War, and following the breakup of the Soviet Union, emerging countries, 'and developed countries as well, are faced with the challenge of demonstrating to their people and to the international community that individual rights and freedoms will be guaranteed through political stability.

The most effective method of embodying such a guarantee is by the promulgation of an enforceable constitution which delineates the general and specific rights and duties of that country's citizens. During the era of the American Revolution, a constitution was defined as establishing

the Basis and ground work of Legislation, and ascertain[ing] the Rights Franchises, Immunities and Liberties of the people, How and how often officers Civil and military shall be elected by the people, and circumscribing and defining the powers of the Rulers, and so affording a sacred Barrier against Tyranny and Despotism. ${ }^{2}$

This note will be divided into three sections. The first part introduces general principles of constitutionalism. The second part analyzes the development of constitutional rights in Russia and in the United States. The third part compares the concepts underlying the United States Constitution with constitutional changes that are currently taking place in Russia.

1. Charles Louis de Secondat, Baron de La Brède et de Montesquieu.

2. Tom N. McInnis, Natural Law in the American Revolutionary Struggle, 26 Legal Studies Forum 41, 49 [hereinafter McInnis]. See also Black's LaW Dictionary 163 (5th ed. 1983) (A constitution is " $t]$ he organic and fundamental law of a nation or state ... laying the basic principles to which its internal life is to be conformed . ."). 


\section{Overview of Constitutionalism}

"In the last two centuries constitutionalism has become established in a position of co-legitimacy with democracy." "3 Because "the evolution of political institutions closely followed the evolution of the doctrine of constitutionalism,"'4 it is necessary to present a general outline of the development of constitutionalism.

While constitutions have been used for centuries to order the "enactment and implementation of public policies, . . . the line of authority between rulers and ruled" only began to become clear during the Roman era. ${ }^{5}$

Modern constitutionalism developed during the monarchical period, when rulers held power as a result of so-called God-given, or natural and inherent, rights. John Locke's conception of a social contract which was binding on the ruler and ruled alike became the generally accepted view. ${ }^{6}$ The belief that all humans were subject to the same laws facilitated the rise in importance of legislatures to express, in Rousseau's words, the general will. ${ }^{7}$ From this eighteenth-century idea of natural and inalienable rights, which would today be called human rights, flows the view that government is an institution created by the people to secure those rights. ${ }^{8}$

Political cohesion was achieved in the monarchical system through the common framework of a belief in God and in an other-worldly accountability for wrong-doing. Both the Church and the nobility held considerable power over the people in the monarchical system. ${ }^{9}$ However, as notions of rights began to spread, and legislatures began to exercise the powers they held as the voice of the people, confusion arose over the jurisdiction and responsibilities of each of the two or more bodies exercising authority. It was, therefore, in each group's best interest to establish regular procedures for the exercise of power, and in this way constitutions came to play an integral role in government.

3. William G. Andrews, Constitutions and Constitutionalism 22 (3d ed. 1968) [hereinafter ANDREws].

4. Id. at 19 .

5. Id.

6. Edward McWhinney, Constitution-Making: Principles, Process, PracTICE 68 (1981) [hereinafter McWHINNEY].

7. Jean-Jacques Rousseau, The Social Contract 76 (Maurice Cranston trans., Penguin Classics 1968) (1762).

8. McWhinNeY, supta note 6 , at 68 .

9. ANDREws, supra note 3, at 19-20. "According to medieval scholastics, the Church and the secular authorities had co-ordinate powers." Id. 
With the rise of absolute monarchs, emerging nation-states had all power lodged in one central authority. Both the Church and the nobility saw their influence wane. Among the first monarchs to succeed in uniting both temporal and spiritual power were King Henry VIII, who ruled England in the sixteenth century, and Louis XIV, King of France in the late seventeenth and early eighteenth centuries. ${ }^{10}$ Revolutions were necessary to abrogate the effects of such despotic regimes and to instill sovereignty in the people of these countries. Constitutions have become prominent following the demise of absolute monarchs or governments.

Attempts by a despotic leader to transcend the traditional framework of the monarchical system and to impose a complete displacement of citizens' rights have been repeated in the United States and in Russia prior to the development of stable constitutional systems in those countries. The monarchical expropriation of the American colonists' natural rights and liberties was made by King George III. The United States Declaration of Independence charges that " $[t]$ he history of the present King of Great Britain is a history of repeated injuries and usurpations, all having in direct object the establishment of an absolute tyranny over these states." 11

In the Soviet Union, the head of the Communist party wielded power comparable to that of a monarch or czar. ${ }^{12}$ The Soviet system embodied what has come to be known as totalitarianism, a system more repressive than dictatorial absolute monarchies. "Unlike a dictatorship, where the ruling elite guilty of the regime's crimes is tiny, a totalitarian regime creates a whole class of rulers [guilty of crimes against the regime]." 13 The Communist party professed to transcend spiritual boundaries by proclaiming that there was nothing beyond the state. "Soviet law is precisely the expression of what is expedient for the construction of socialism and the fight for socialism." 14

For a constitution to be of value in protecting a society against tyrannical excesses, the rule of law must have a strong foundation, because a constitution means nothing if the law is not supreme. "Laws

10. Id. at 20 .

11. The Declaration of Independence para. 2 (U.S. 1776).

12. Some, in fact, question whether or not the 1917 "Revolution" was really a revolution at all. See Abbott Gleason, Russia: The Meaning of 1917, AtLantic Monthly, Nov. 1992, at 30 .

13. Vladimir Bukovsky, Totalitarianism in Crisis: Is There a Smooth Transition to Democracy?, in Totalitarianism at the Crossroads 15 (Ellen Frankel Paul ed., 1990) [hereinafter Bukovsky].

14. David Forte, Western Law and Communist Dictatorship, 32 Emory L.J. 135, 181 (1983). 
change, but the Law must remain, and with it the fundamental values; a law which contravenes that Higher Law is not a law at all." 15 Moreover, the fundamental values embodied in a constitution must be contemporary, not based on archaic principles. ${ }^{16}$ When the Soviet Union developed its first constitution, it did not attempt to incorporate the Enlightenment ideas of rights because such a notion was considered by Marxist-Leninists to be based on the exploitation of the working class by the capitalist class, an archaic condition which communism professed to destroy.

According to communist dogma, capitalism was merely an evolutionary step on the human ladder that would ascend to communism. The notion of a rule of law was antithetical to communism's main tenet: as the workers, or proletariat, developed consciousness of their exploitation by the capitalist class, bourgeois laws would disappear, resulting in 'homo Sovieticus.' 'Homo Sovieticus' was to be the end product of human development, a being so perfect that laws would not be tolerated. ${ }^{17}$ One element of Soviet legal ideology was the rejection of the notion that man by his very nature is endowed with certain inalienable rights.

Following the destruction of communism in the Union of Soviet Socialist Republics, Russians are faced with the task of formulating a constitution which will direct their government and society. A constitutional commission under the direction of Oleg Rumantsyev produced a draft constitution in 1992 which has drawn heated discussion from all quarters of Russian life. ${ }^{18}$ Just as the fundamental values asserted in the Declaration of Independence sought to guarantee American citizens the right to "life, liberty and the pursuit of happiness," 19 and the United States Constitution "secures the blessings of liberty to ourselves and our posterity," ${ }^{20}$ the draft Constitution of the Russian Federation guarantees "the rights and liberties of man and citizen according to ... the generally accepted principles and rules of international law.",21 (1971).

15. Mauro Cappeleetti, Judicial Review in the Contemporary World vii

16. MaWhinNeY, supra note 6 , at 69 .

17. Christopher Osakwe, The Four Images of Soviet Law: A Philosophical Analysis of the Soviet Legal System, 21 TEx. INT'L L.J. 1, 4 (1985).

18. Andrei Chernov, Russia Without Despotism and Despots, Moskovskiye Novosti, Apr. 5, 1992, at 6, available in LEXIS, Nexis Library, Intl File.

19. The Declaration of Independence para. 2 (U.S. 1776).

20. U.S. Const. pmbl.

21. Kontstitutsiia RF $₫ 1$, art. 2, para. 2 (1992) (Russia) (draft) [hereinafter Draft], available in LEXIS, Nexis Library, Intl File. See infra notes 86.89 and accompanying text. 
Because a constitutional government is a limited government, ${ }^{22}$ consensus on the forms of state institutions and procedures is especially important. "If general agreement on the desirability of the survival of the state breaks down, civil war or revolution may result." ${ }^{23}$ Procedural prescriptions, which establish the foundation of the political society, have been successfully incorporated into western notions of government constitutional power as early 400 B.C. in the Greek city-states.

In addition to procedural limitations, however, a constitution must also provide for the proscription of power. Principles once considered inviolable that were disregarded by such legislative tyranny as in the Nazi-Fascist era are now being put in written form to provide legal barriers against their violation. "Constitutional restraints on state authority are essential in socialist countries if they are to fulfill aspirations to be less oppressive than capitalist ones." ${ }_{24}$

When implementing a constitution, the proscription of power takes two forms: the separation of powers into different branches, and the separation of functions. ${ }^{25}$ A separation of functions takes place in "fullyevolved parliamentary regimes." ${ }^{26}$ In either case, the arbiter is a broad, popular electorate. ${ }^{27}$

Modern constitutionalism incorporates ideas of popular sovereignty, consent of the governed, accountability of officials to the people, the rule of law, the constitution as the supreme law, and government limited by separation or diffusion of powers and by checks and balances. ${ }^{28}$ "Most importantly, constitutionalism implies respect for individual rights and contemplates some. means of assuring that respect . . . " "29 Whatever its contents, a constitution will not be able to provide for every possible

22. ANDREws, supra note 3 , at 13. The purpose of a prescriptive constitution is to establish limits on governmental action. A descriptive constitution, on the other hand, serves merely to guide the policy-making branch or branches of the government. Id.

23. Id. at 9 .

24. Paul Q. Hirst, Law, Socialism and Democracy 85 (1986).

25. ANDREWS, supra note 3 , at 21 .

26. Id.

27. Id.

28. Louis Henkin, Revolutions and Constitutions, 49 LA. L. REv. 1023, 1035 (1989) [hereinafter Henkin]. The notion of a separation of powers is embodied in the United States Constitution and was first developed by Montesquieu. According to Montesquieu, "[s]o that one cannot abuse power, power must check power by the arrangement of things." Montesquieu, The Spirit of the Laws 155 (Anne M. Cohler et al. eds., 1990) (1748).

29. Henkin, supra note 28 , at 1035. 
right or freedom. Many things must be settled by practice because "over-anticipation is a fault of pedantry and of distrust." 30

\section{Historical Development of Constitutionalism}

\section{A. American Constitutional Development}

The thirteen newly independent American states greatly feared relinquishing any power to a central government that might usurp power to the extent that England had. The states therefore agreed to form a loose confederation under the Articles of Confederation, which allowed them to have broad powers over the national congress.

Each state agreed to relinquish certain powers to the central government. In return, each state retained authority over virtually everything that occurred within its borders. The structure of the central government consisted of a unicameral congress which was responsible for executive, legislative, and judicial functions. ${ }^{31}$ According to Thomas Jefferson, the areas in which the national government had competence to act were international relations and defense. ${ }^{32}$ One of the major shortcomings of the Articles was the inability of the central government to collect taxes from the states for operation of the national government. ${ }^{33}$

The Articles of Confederation failed to address major problems of unity and administration among the states. Nevertheless, "[ $t]$ he federal idea ... finds its historical origins in the Articles of Confederation . . . ."34 Consequently, the Constitutional Convention, which convened in Philadelphia in 1787, became a debate to enact an effective government. ${ }^{35}$ While the delegates to the Constitutional Convention represented ideologically diverse viewpoints and interests, the goal of the Convention was to protect liberty by reducing the chance that a tyrannical faction would be able to wrest power from the legitimate government. ${ }^{36}$

30. Ruth Wedgwood, The Revolutionary Martyrdom of Jonathan Robbins, 100 YALE L.J. 229, 258 (1990).

31. J.W. Peltason, Corwin and Peltason's Understanding the Constitution 9 (9th ed. 1982). The national government was run, in Congress' absence, by an administration consisting of one person from each state. Id.

32. Akhil Reed Amar, Approaching Democracy: A New Legal Order for Eastern Europe, 58 U. ChI. L. Rev. 483, 489 (1991).

33. Peltason, supra note 31 , at 9 .

34. McWhinney, supra note 6 , at 75 (emphasis in original).

35. Peltason, supra note 31 , at 11 .

36. Id. at 11-12. 
The delegates distrusted any government dominated by a single faction, whether composed of one person, as in a monarchy; a small group of people, such as in an oligarchy; or even a larger group, called "a tyranny of the majority.",37 A balance between factions results in what is termed a mixed regime. Cicero and Montesquieu both conceived of a mixed regime as including monarchy, oligarchy, and democracy. ${ }^{38}$ Aristotle, on the other hand, viewed a mixed regime in terms of democracy and oligarchy. ${ }^{39}$

Many delegates to the Constitutional Convention feared that democracy would facilitate tyranny. ${ }^{40}$ In order to avoid a tyranny of the majority, a check was placed upon the democratic tendencies of government. The United States Constitution accomplishes this by countering the democratic House of Representatives with the competing faction of aristocracy embodied in the Senate. ${ }^{41}$

In the United States Constitution, a mixed regime was created by diffusing power at the national level into three independent branches: the executive, the legislative, and the judicial. Each branch has areas of specific jurisdiction, and each acts to ensure that no branch oversteps its mandate. Furthermore, power is shared between the national government and smaller units. These smaller units, composed of states, local governments, and individuals, retain power in certain instances while sharing power jointly with other state, local or individual units, or with the national government in some instances, or while relinquishing power to the national government in other cases.

These ideas of federalism, and the separation of powers, along with the closely related notion of governmental checks and balances, have become well known for the governmental stability they have established under the Constitution of the United States of America.

\section{B. Russian Constitutional Development}

The development of a meaningful constitution in Russia has taken somewhat longer than in the United States. As was the case in a number

37. Algksandr Solzhenitsyn, Rebuilding Russia: Reflections and Tentative Proposals 63 (1991) [hereinafter Solzhenitsyn] ("For John Stuart Mill, unlimited democracy held the danger of the tyranny of the majority ...").

38. Paul Eidelberg, The Philosophy of the American Constitution: A Reinterpretation of the Intentions of the Founding Fathers 112 (1986) [hereinafter EIDELBERG].

39. Id.

40. Id. at 260 .

41. Id. 
of Western countries, the ideology of constitutionalism has been developing in Russia since the eighteenth century. In France, the Declaration of the Rights of Man and of the Citizen, promulgated in 1789, marked the beginning of the French constitutional era. Likewise in Russia, Catherine the Great sought to ascertain the "natural laws on which the legislation of her empire should repose." 42

The Decembrists' Revolt, which was put down in 1825, sought to introduce a constitutional framework to the Russian czarist system. The Decembrists are credited with being Russia's first revolutionary movement. ${ }^{43}$ Although they knew that their own deaths would be the probable result of their actions, they nevertheless sought to create a constitutional monarchy with an elected legislature. "The blood of the . . Decembrists whetted the appetite of [the Russian-Soviet] state."

Under Bolshevik control of Russia following the October Revolution of 1917, Lenin sought to ensure the success of a worldwide proletarian revolution. The initial Soviet Constitution was primarily a reflection of the "revolutionary Marxist stage of Soviet reality" of the early Bolshevik government. ${ }^{45}$ The first Soviet constitution was used to supplement the socialist conscience of the revolutionary judges until communism could become strong enough to perfect human development. ${ }^{46}$ This Constitution, ratified in 1918, did not order legal relationships, it "merely provided the ideological signal of what those relationships should be and what those purposes were." 47 The Soviet Constitutions, therefore, did not so much proscribe power as describe the goals of the Soviet government.

When Josef Stalin took control of the USSR, the Communist Party of the Soviet Union (CPSU) largely abandoned the illusion that the workers of the world would unite. Instead, Stalin concentrated on building "socialism in one country" by fortifying and strengthening communism in the countries comprising the Soviet Union until the Communist system could become strong enough to overpower capitalism. ${ }^{48}$ This entrenchment was marked by the passage of a new constitution in 1936.

42. Geoffrey Bruun, The Enlightened Despots 76 (1967).

43. Christopher Andrew and Oleg Gordievsky, KGB: The Inside Story 18 (1990).

44. Aleksandr I. Solzhenitsyn, The Gulag Archipelago 433 (Thomas P. Whitney trans., Harper \& Row 1974).

45. Forte, supra note 15 , at 165 .

46. Id.

47. Id. at 166 .

48. Adam Ulan, Perestroika and Ideology, in Totalitarianism at the Crossroads, supra note 13 , at 37 [hereinafter Ulan]. 
The 1936 constitution granted broad individual rights. However, these rights, as was the case with the first Soviet Constitution as well, were not enforceable for two reasons. First, while broad rights were granted, other constitutional provisions made antisocial behavior illegal. Yet, antisocial behavior was broadly defined. Under Lenin's Criminal Code of 1922, crime was defined as "every socially dangerous action or inaction that threatens the foundations of the Soviet system." ${ }_{49} \mathrm{Sec}-$ ond, no court had jurisdiction over constitutional questions. ${ }^{50}$ All government power was unified. The judiciary was subordinated to oversight by the political branches of government. "[T]he CPSU, acting like a Hobbesian sovereign, [oversaw] all organs of the government." 51

Nikita Khrushchev's major legacy was in helping Soviet society recognize governmental reorganization in the post-Stalin era. "Khrushchev sought to cleanse, rather than to reform, the Soviet system." ${ }_{52}$ In the process, a greater degree of openness was permitted. Leonid Brezhnev succeeded Khrushchev and tried to establish a firm hold on the party and society, but he did not have enough of a "cult-of-personality" to rule as authoritatively as Stalin had. ${ }^{53}$ Consequently, dissatisfaction was voiced in an effort to take advantage of the textual constitutional rights. The optimistic period of the Khrushchev generation set the Russian people up for the "crushing disillusionment of the long, painful decline under Brezhnev." "54 The 1977 constitution, which was ratified under Brezhnev, made cosmetic reforms but did not change the ruling institutions. This enabled the CPSU to maintain a constitutional stranglehold on the rights of the Russian people.

Following Mikhail Gorbachev's ascent to power, the Communist party began to acknowledge that it did not play the primary role in Soviet society. This realization, along with "growing declines in industrial and agricultural output, soaring inflation and budget deficits, and the run-down of foreign trade and the exchange reserves," ${ }_{55}$ caused

49. Roger Scruton, Totalitarianism and the Rule of Law, in Totalitarianism AT THE Crossroads, supta note 13 , at 198-99.

50. ANDREWs, supra note 3 , at 154 .

51. Osakwe, supra note 17 , at 16 .

52. Ulan, supra note 48 , at 33 .

53. "The Brezhnev era probably came closest to what might be described as a period of stability in Soviet history." This is because the Soviet Union managed to maintain a semblance of status quo while the United States was dealing with such crises as the Watergate scandal and Vietnam, and the West was facing the Mid-East oil embargo. Furthermore, following Mao's death in 1976, China seemed ready to plunge into instability. Id. at 34 .

54. Hedrick Smith, The New Russians 21 (1990).

55. Memorandum from Adolphe J. Warner, Chairman, Global Asset Management 
Russians and non-Russians alike to question the legitimacy of the Soviet government.

The Baltic states, claiming that only Soviet hegemony had kept them in the Soviet Union, solidified their freedom as independent states in the early 1990's. While some republics of the former Soviet Union followed the example of the Baltics, other republics sought only to assert more governmental autonomy, and still maintain advantageous alliances with the former central government and with other republics.

In response to a mounting economic crisis and secessionist drive by republics, the Politburo attempted to reestablish CPSU dominance of the regular legislative process. The failed conservative coup of August 1991 demonstrated that there could be no retreat without a bloody struggle from a state in which legitimacy is derived from the people, not from a political party or faction. President Boris Yeltsin, when faced with a situation that paralleled the 1917 revolution, chose to support a peaceful transition to a free society instead of winning approval with bullets..$^{56}$

\section{Contemporary Comparison of Constitutional Rights}

\section{A. Weaknesses of the Post-Coup Government}

In an historical context, the people of Russia in the late twentieth century face problems similar to those that confronted the thirteen American colonies more than two hundred years earlier. After the colonies had broken with England, they attempted to collaborate under the Articles of Confederation. The Articles, however, proved incapable of maintaining unity and stability between the semi-autonomous states.

Many colonists feared a return to şome form of dictatorial regime because of the weak and disjointed central government. Prior to the ratification of the Constitution, the United States was not a unified country. "Religious differences were significant and potentially dangerous. . . Regional differences were sharply marked." 57 Although the one thing agreed upon was the need to protect liberty, there nevertheless

Associates, The Old Ruble Must Go Now: Why Currency Reform Can't Wait (Sept. 13, 1991), available in WESTLAW, PRNEWS Database).

56. Gavril Popov, Popov on ' 91 Coup, Current Digest of the Soviet Press, Sept. 23, 1992, at 1, available in LEXIS, Nexis Library, Intl File.

57. President Jimmy Carter, Keynote Address: The United States and the Advancement of Human Rights Around the World, 40 EMORY L.J. 723, 724. For a contemporary treatment of the regional divisiveness of slavery, see Douglas L. Wilson, Thomas Jefferson and the Character Issue, Atlantic Monthly, Nov. 1992, at 57. 
"were differences over what form governments should take." 58

In the aftermath of the failed 1991 coup, the Russian government and its ruling institutions have been weak and ineffective. The republics that once comprised the Soviet Union have been free to follow their own course. In addition, many of the ethnically diverse regions within the territory of Russia and the other former Soviet republics are threatening separation by violent means.

The legislature, which is the main institution of procedural democracy, is blocking reforms. ${ }^{59}$ President Yeltsin took sole responsibility for the reforms by denying the legislature the right to form a cabinet. As a result, the legislature no longer had a role in guiding the reforms and instead began to criticize Yeltsin's moves at every opportunity. ${ }^{60}$ Currently, the legislature is not only hindering the exercise of executive power, but has also encroached on the functions of the executive as well. Ruslan Khasbulatov, Chairman of the Supreme Soviet, is "for all practical purposes the second head of the executive branch." 61 Furthermore, Chairman Khasbulatov has declared that the budget power is the primary state power ${ }^{62}$, which suggests that a loose alliance of semi-sovereign states resembling the United States under the Articles of Confederation is likely to encounter serious problems.

A number of additional considerations may make the situation in Russia more difficult to resolve than the problems that faced the framers of the United States Constitution. First, because English tyranny over the American colonies was imposed from outside, the vestiges of English rule were more easily swept aside, so the new system more readily flourished. The American break with England might today be called a "'war of 'people's liberation,' a war for self-determination against external and distant forces." 63

In Russia, on the other hand, the tendrils of CPSU power have penetrated every square inch of Russian life, requiring the establishment of a totally new system of government. "If a revolution destroys a systematic government, but the systematic patterns of thought that

58. McInnis, supra note 2, at 52 .

59. Press Conference by Boris Yeltsin (pt. 1) (Russian Television, June 9, 1991), available in LEXIS, Nexis Library, Currnt File.

60. Lyudmila Telen, Power vs. Power, Moscow News, April 15, 1992, available in LEXIS, Nexis Library, Intl File.

61. August Mishin, Hopes for a Constitution Die Hard, Moscow News, Sept. 9, 1992, available in LEXIS, Nexis Library, Intl File.

62. Speech by Ruslan Khasbulatov Urging Deputies to Adopt the Draft Constitution (Russia's Radio, Apr. 17, 1992), available in LEXIS, Nexis Library, Currnt File.

63. Louis Henkin, supra note 28 , at 1034 . 
produced that government are left intact, then those patterns will repeat themselves in the succeeding government." 64 Montesquieu's words can easily be applied to the succession of authoritarian rulers throughout the history of Russia and the Soviet Union; "all the blows were struck against tyrants, none against tyranny." 65

A number of authors have noted that authoritarian strains run deep in Russia. ${ }^{66}$ Events at the top cause repercussions throughout the country ${ }^{67}$ Indeed, the systematic patterns of thought that underlie Communist and Czarist Russian authoritarianism are still present, despite efforts by President Boris Yeltsin and other Russian democrats and reformists to ground government legitimacy firmly on the rule of law.

The CPSU was banned in Russia in November 1991. Criminal charges have been brought against the party for its role in, and execution of, the August 1991 attempted coup designed to oust the legally elected government. ${ }^{68}$ Because the CPSU made state property determinations and state budget appropriations without any accountability to the people, and because the KGB was officially employed as an "armed detachment of the party which [acted] under control of the CPSU leadership," the property of the CPSU has been nationalized. ${ }^{69}$

Moreover, a great number of Russian citizens participated in the tyranny, either in an official capacity, such as in the army or KGB, or in a more discreet manner, as in the large number of informers who implicated neighbors or others in crimes against the state. Many people have questioned Yeltsin's motives in banning the CPSU and the farright party National Salvation Front..$^{70}$ In light of these steps, one might

64. Robert M. Pirsig, Zen and the Art of Motorcycle Maintenance 88 (Bantam New Age ed., 1981).

65. Montesquieu, supra note 28 , at 22.

66. According to Leonid Abalkin, a Russian historian, one reason that the Communist government was able to gain power was because the "authorities had always been prone to tyranny ... ." Lyudmila Alexandrova, Scholars Discuss Russian Revolution Heritage, TASS, Nov. 6, 1992, available in LEXIS, Nexis Library, Currnt File. See also infra note 82.

67. Telen, supra note 60. See also Popov, supra note 56.

68. The CPSU Was Banned, Not the Communists; Nobody is Persecuting Them (Official Kremlin Int'l News Broadcast, May 26, 1992), available in LEXIS, Nexis Library, Currnt File.

69. Id.

70. The Russian Federation Constitutional Court ruled that President Yeitsin's decree "banning the creation and activity of the National Salvation Front and its structures, does not correspond with the Russian Federation Constitution ...." The Court pointed out that the term "extremist elements" was overly broad and the 
begin to see new meaning in the words of the former Communist premier, Anatoly Lukyanov, who said from his jail cell that from a legal and political point of view, actions by the democratic government of Russia to ban and discredit the CPSU and other extremist parties must be looked at as an attempt to "get rid of a strong political opposition." 71

In addition to the intransigence caused by an entrenched resistance to Enlightenment ideals, a second problem developing in Russia is the potentially devastating economic conditions facing the country. A primary obstacle to economic reform is the development of a currency that is convertible on the world market. Bound up with the fate of the Russian ruble is the axiom that "economic policies follow political trends in the short run, while the reverse holds true in the longer run." 72 The failure of the Soviet Union is not so surprising then, considering the drastic economic conditions that prevailed preceding the 1991 coup attempt. $^{73}$

The problem is complicated by the experience of other former Communist countries which have attempted a currency exchange and have found individual larceny to be pervasive and hard to avoid. ${ }^{74}$ Russian law enforcement officials have already encountered individual larceny as the society transforms from a planned economy to a freemarket economy, because more favorable conditions are created for criminals to evade the authorities. "The old command economy has broken down, but no market system exists to succeed it."

application of this decree could lead to violations of citizen's constitutional rights. Russian Federation Constitutional Court, Decree 3-P, February 12, 1993, available in LEXIS, Nexis Library, Intl File.

71. Interview from Behind the Bars (Official Kremlin Int'l News Broadcast, Sept. 18, 1992) available in LEXIS, Nexis Library, Currnt File [hereinafter Lukyanov] (Lukyanov had been arrested for taking part in the coup but has since been released).

72. Adolphe J. Warner, supra note 55 .

73. One illustration of the failure of the Soviet economy is the extent to which natural resources have been degraded under Soviet control. Total environmental damage caused by air and water pollution was estimated at twenty billion rubles at the end of the 1970's, with projections at the end of the 1990's as high as 120 billion rubles. Revolutionary Communist philosophy rejected the idea that nature should be given protection from the enterprises of the state. Communists "cannot wait for favors from nature. Our task is to take them from her." Bukovsky, supra note 14 at 27.

74. Adolphe J. Warner, supra note 55.

75. Crime in Russia, UPI, Sept. 16, 1992, available in LEXIS, Nexis Library, UPI-Daily File.

76. Robert B. Zoellick, Relations of the United States with the Soviet Union and the Republics, Statement Before the Subcommittee on Europe and the Middle 
rise in crime spreading across the former Soviet Union is encouraged by the absence of stability in the ruling institutions, such behavior cannot be blamed solely on the attempted establishment of democracy. "No constitutions, laws, or elections will, by themselves, assure equilibrium in a society, because it is human to persist in the pursuit of one's interests." 77 Only to the extent that market relations become normalized will a rule of law stabilize. ${ }^{78}$

A third problem confronting the Russian Federation is the effect which the former Communist regime continues to have on Russian society. Although the Soviet Union has been dissolved and the CPSU outlawed, the current government must function under a modified version of the 1977 Soviet Constitution, which was ratified under Leonid Brezhnev. While key provisions have been deleted to allow for a multiparty system and for limited ownership of private property, the modified Brezhnev Constitution nevertheless continues to make the state's interests supreme over the individual, to give priority to state property over private property, and to punish violations of public order more severely than violations of individual rights. ${ }^{79}$

The Soviet legacy goes far beyond the doctored Brezhnev Constitution. The attitude of many Russians can be summed up in the words of Anatoly Lukyanov, who asserted that "[b]y allowing all kinds of political adventurists to step on the memory of the millions of Communists who gave their lives for the cause of the working class, for socialism and for the defeat of fascism, then we betray ourselves, our ancestors and our history." 80 Indeed, that a government has succeeded in maintaining complete control over millions of people by repressive measures in the name of the liberation of the proletariat is not a sufficient explanation for the seventy-five year hegemony of the Soviet one-party system. Because "government could not be unjust without hands to exercise its injustices," pluralism by the leadership . . . without taking into account the weakness

East of the House Foreign Affairs Committee (October 2, 1991), in Dep'r ST. DisP., October 7, 1991.

77. SolzhenitsYN, supra note 37 , at 54 . In fact, crime, and other behavior labelled as anti-social, had been on the rise under the Soviet system for some time. In 1983 there were 40 million "medically certified alcoholics," a number that was projected to double by the year 2000. Bukovsky, supra note 13 , at 27 .

78. Steven Erlanger, Discovering Justice: Russia and the Law, The New York Times, May 11, 1992, at Section A, Page 1, Column 1.

79. Id.

80. Lukyanov, supra note 71.

81. Montesquieu, supra note 28 , at 65. 
of democratic ideas, beliefs, and traditions in Russia throughout its history." 82

Finally, the development of a multiparty democratic regime has been hindered by the governmental structure of the former Soviet Union. Because of the condemnation and repression of pluralism by the CPSU, a weak differentiation between individual and social groups has developed, along with insufficient awareness of those groups on a political level. ${ }^{83}$ Furthermore, the vertical power structure of the Soviet government, in which orders from party leaders filtered down through the chain of command, has resulted in the lack of a well-established legislative base on which to develop a consistent state policy towards political parties. ${ }^{84}$ The very discrediting of the CPSU has hindered the development of pluralism by giving political parties in general a bad name.

\section{B. Post-Soviet Constitutional Development}

While the problems facing Russia are very serious, they are not insurmountable. A necessary first step, however, is to establish the foundation on which the Russian government will proceed. During the American Revolution,

[d]isagreements over how to best construct a government which exemplified the principles of natural law . . . led to a period of experimentation in the creation of state constitutions. ...

It was the unhappiness with the results of these experiments and their seeming inability to inspire public virtue and $\mathrm{Re}$ publican consciousness on the part of their citizens which brought forth calls for a stronger national government. ${ }^{85}$

The Constitutional Commission charged with developing a constitution produced a lengthy document in 1992 which granted very broad individual and social rights. Among the rights granted in the fifty page charter $^{86}$ were the right of recreation ${ }^{87}$, the right to a "favourable environment" ${ }^{88}$ and provisions guaranteeing a social state. ${ }^{89}$ However,

82. Robert A. Dahl, Democracy and Its Critics 262 (1989).

83. Vyacheslav Nikonov, Ideas and People: On the Near Approaches to Power Thoughts on Russian 'Party Building', Nezavisimaya Gazeta, Aug. 7, 1992, at 5, available in LEXIS, Nexis Library, Intl File.

84. Id.

85. McInnis, supra note 2 , at 58 .

86. The draft constitution contained six titles, twenty-five chapters, and 136 sections. Draft, supra note 21.

87. Draft, supra note 21 , article 36 .

88. Id. art. 38 .

89. Id. art. 39 . 
concensus was never reached on the draft constitution as a result of disagreement over the structure and the power-sharing arrangement of the proposed federal government.

A number of attempts have been made to find a solution to the question of how power is to be divided between the three branches of government. The disagreement over the shape and structure of the Russian Federation government has developed into a battle for supremacy between the executive branch, represented by President Boris Yeltsin and supporters of the reforms, and the legislative branch, represented by Supreme Soviet Chairman Ruslan Khasbulatov'and conservative members of the former Communist regime.

President Yeltsin attempted to ameliorate the power struggle by asking for the opinion of the citizens of Russia in a national referendum. The Congress of People's Deputies formulated the four questions to be put to the eligible voters, which were approved by the Constitutional Court. (1) Do you trust Russian Federation President Boris Yeltsin? (2) Do you appove of the Socio-Economic policy implemented by the Russian Federation president and government since 1992? (3) Do you think it necessary to hold early elections of the Russian Federation President? (4) Do you think it necessary to hold early elections of the Russian Federation People's Deputies? ${ }^{90}$

The referendum was held on Sunday, April 25, 1993. Early returns were very favorable to President Yeltsin, however, no substantive gains appear possible. According to a Constitutional Court ruling, the first two questions, relating to confidence in the president and his policies, required only a majority of those voting, while for early elections to be mandated, the required vote was at least a majority of the eligible 105 million voters. Without such early elections, Russia seems certain to face continued struggle between the two dominant branches of government. This means that those who claim to rule Russia will continue to be distracted from the two most pressing requirements for continued stability of Russian society: the development of a federal constitution that will guarantee basic rights to every citizen, and reform of the economy that will allow Russian society to prosper and develop on the world market.

In a federal government, a constitution divides governmental power between a central and subdivisional governments, giving to each sub-

90. Russian Congress of People's Deputies, Resolution 4684-1, On the All-Russian Referendum on 25th April, 1993, (March 29, 1993), available in LEXIS, Nexis Library, Intl File. 
stantial functions. ${ }^{91}$ A federal constitution must make the national government supreme, with the constitution assuming the role of supreme law of the land. ${ }^{92}$ According to the preamble of the 1992 draft Constitution, "We, the multinational people of the Russian Federation . . . adopt the constitution of the Russian Federation and proclaim it THE BASIC LAW OF OUR SOCIETY AND STATE." "93 In a federal government, the constitution grants legislative, executive, and judicial powers to the national government. ${ }^{94}$

The Constitutional Commission's Draft Constitution incorporated sections detailing the functions of the executive, the legislative, and the judicial functions envisioned by the Commission. In the draft, the legislative jurisdiction included all policy areas, consisting of domestic, foreign, and defense policy ${ }^{95}$, determining and enforcing jurisdictional questions through enactment of federal laws ${ }^{96}$, and nominating judges of kray and oblast courts (which are analogous to United States state and municipal courts) subject to presidential approval. ${ }^{97}$ The strength of this parliamentary body was added to considerably by giving to the legislature supervisory powers over the activities of the executive branch ${ }^{98}$, power to pose and decide "the question of the resignation of the members of the government of the Russian Federation" dismiss the president, ${ }^{100}$ negotiate treaties, ${ }^{101}$ declare, extend or cancel states of emergency, and decide war and peace. ${ }^{102}$

Under the plan outlined by the Constitutional Commission, the president was to be the highest official of the Russian Federation and the head of the executive branch. ${ }^{103}$ The president was to be elected directly by the people and could serve a maximum of two five-year terms. ${ }^{104}$ This provision demonstrates Russia's commitment to legiti-

91. Peltason, supra note 31 , at 16 .

92. Id.

93. Draft, supra note 21, Preamble (emphasis in original). While the draft has been rejected, the importance being given to a Constitution as the fundamental law of Russia shows that the Russian people demand accountability from their government.

94. Peltason, supra note 31 , at 16.

95. Draft, supra note 21 , art. $88(\mathrm{~b})$.

96. Id. art. 88(a).

97. Id. art. $88(\mathrm{j})$.

98. Id. art. $88(1)$.

99. Id.

100. Id. art. $88(\mathrm{~m})$.

101. Id. art. 88(n).

102. Id. art. $88(\mathrm{q})$.

103. Id. art. 95(1).

104. Id. art. 95(4). 
mizing the government through the approval of the people by avoiding the type of compromise the United States employs in the electoral college.

The judicial functions of the draft Russian Federation Constitution embodied supreme judicial power in a Constitutional Court, which was to be composed of fifteen members ${ }^{105}$ appointed by the president of the Federation subject to the approval of the Supreme Soviet. ${ }^{106}$ The Constitutional Court was to preside over the Supreme Court ${ }^{107}$ and the Supreme Economic Court ${ }^{108}$, which would govern matters relating to civil, criminal, and administrative cases, and economic questions, respectively.

\section{Problems Facing Constitutionalism}

If the executive power does not have the right to check the enterprises of the legislative body, the latter will be despotic, for it will wipe out all the other powers, since it will be able to give itself all the power it can imagine. But the legislative branch cannot be able to check the executive-the legislative body should not have the power to judge the person, and consequently the conduct, of the one who executes. ${ }^{109}$

The constitution must create a balance in governmental powers so that the executive does not destroy the legislative right to adopt laws, and so that the legislature cannot overstep its mandate. If the legislature is able to impose extensive checks on the executive branch, then the legislature, in effect, subsumes the powers of the executive.

The draft constitution would have given an extremely broad range of power to the Supreme Soviet. These powers would have allowed the legislature to control certain aspects of the executive branch. Such a scheme did not "rule out a return to a totalitarian state but, on the contrary, objectively facilitate[d] this." 110 Furthermore, despite the fact that the powers generally within the purview of the legislature are the discussion and adoption of laws, the Supreme Soviet and its Chairman, Ruslan Khasbulatov, are purposefully "acquiring more and more power,"

105. Id. art. 106.

106. Id. art. $96(\mathrm{e})$.

107. Id. art. 107.

108. Id. art. 108.

109. Montesquieu, supra note 28 , at 162 .

110. Andrei Chernov, Russia Without Despotism and Despots, Moskovkiye Novosti, Apr. 5, 1992, at 6, available in LEXIS, Nexis Library, Currnt File. 
by creating executive structures under the Supreme Soviet. ${ }^{111}$

Second, the national/state structure duplicates the apportionment of powers that existed under the Soviet government. An alternative draft constitution presented by Anatoly Sobchak "seeks to replace these divisions with new administrative areas-on the basis that the old are hopelessly enmired in the structures of the old regime and cannot be 'democratised' simply by being shifted under the aegis of a presidential, or for that matter a parliamentary, republic." 112

Third, the stability engendered by the United States Constitutional system of staggered elections has not been incorporated into the draft Russian Federation Constitution. The problems that developed following the 1991 coup are due in part to the fact that deputies to the congress were elected en masse three years before the coup, and therefore did not reflect the prevailing situation of a society undergoing change. Finally, the jurisdiction of the Supreme Soviet, would have, in effect, been determined and enforced by the Supreme Soviet itself. ${ }^{113}$

The future of the Russian Federation is unclear. With no constitution addressed to the specific concerns of post-Soviet society, the stability of the Russian government is questionable. The powers held by the three different branches are ambiguous and conflicting. In the face of hyperinflation and massive unemployment, President Yeltsin and democratic reforms continue to have the approval of the Russian people, while the Congress of People's Deputies are increasingly being seen as intransigent and regressive. Composed mainly of hard-line conservatives elected prior to the 1991 coup, and due to serve until their terms end in 1995, the Congress of People's Deputies holds the reins of promoting a new constitution. However, given the composition of the Congress, the Communist constitution may have as much influence on the future of the Russian Federation as ideas embodied in the United States or other modern Constitutions.

\section{Conclusion}

Constitutionalism is a guiding force in the evolution of modern nation-states. Constitutionalism developed within the framework of the monarchical system as rights which had previously been held only by the ruler became fundamental rights of the people as well. As legislatures became the voice of the people, constitutions were promulgated to solidify

111. Id.

112. John Lloyd, Survey of the Reforming Russia, Financial Times, May 13, 1992.

113. Draft, supra note 21, art. 88(a). 
the relationships between the ruling institutions and the people.

The United States Constitution established a system based on individual rights and the limitations on state power. While Russia has encountered constitutional ideas over the years, constitutionalism has never been fully assimilated. Following the demise of the Soviet Union, Russia is at a major turning point. Either a new constitution will establish a system that is supreme over every individual, or constitutionalism will continue to occupy a strictly educational and descriptive role, embodying lofty principles that are not readily attainable.

The Enlightenment ideals that served as the backdrop to the Philadelphia Convention in 1787 should be reappraised in light of the needs of Russia today. Given the tendency of strong leaders to win the political support of Russians, a system needs to be encouraged that will focus more on the process than on the participants. Each governmental branch must have enough authority to accomplish its objectives, but must not be able to overtake the functions of other branches to the point that any one faction gains ascendancy of the government as a whole, as the Communist party did following the October Revolution of 1917.

Finally, any constitution must be flexible enough to cope with significant changes in society. The ethnic divisions and economic troubles facing Russia require imaginative solutions, solutions which can be developed without destroying the rights and freedoms of the citizens of Russia.

Michael P. Chauvin*

* J.D. Candidate, 1994, Indiana University School of Law-Indianapolis. 